\title{
Self-Knowledge as a Technology of the Self: Foucault and Wittgenstein on the Practice of Philosophy
}

Jörg Volbers, Berlin

The goal of philosophy is, as Wittgenstein famously put it, to help the fly out of the fly-bottle. Socrates, in the Apology, uses the image of the philosopher being a fly in a quite different manner. He compares his philosophical activity with a horsefly which is stinging the proud state of Athens which has, as Socrates puts it, become "tardy in his motions owing to his very size, and requires to be stirred to life."1 Now it is obvious that both philosophers describe a completely different setting. Socrates defends his philosophical activity with reference to a moral obligation; a duty to stir up the citizens of Athens in order to prevent them from leading a mindless, an unexamined life. He will never cease, he claims, to stop and interrupt the Athenians and ask them whether they are "not ashamed of heaping up the greatest amount of money and honor and reputation, and caring so little about wisdom and truth and the greatest improvement of the soul"? ${ }^{2}$ It is the care of the soul, or, to use an apt expression of Michel Foucault, the 'care of the self' at which Socrates' intervention on the agora aims. In this respect, Socrates can be said to represent the dominant philosophical ideal of antiquity: Philosophy is thought of as a noble, moral activity, which tries to form the philosophizing subject rather than just informing it. $^{3}$

${ }^{1}$ Plato, Apology, 30e.

2 Plato, Apology, 29d.

${ }^{3}$ The notion of the 'care of the self' is introduced in the $2^{\text {nd }}$ volume of Foucault's History of Sexuality. Foucault's interpretation of antiquity owes quite a lot to the studies of Pierre Hadot, who, in turn, was an attentive reader of Wittgenstein. Hadot's interpretation of ancient philosophy can be found in Hadot 2002; his articles about Wittgenstein are collected in Hadot 2004. 
Wittgenstein, on the other hand, seems to have a methodological problem in mind. There is evidence in his unpublished notes that his remark about the fly-bottle initially was targeting at the solipsist. ${ }^{4}$ The solipsist holds that there can be no thoughts, emotions or experiences other than his own; he is the speaker of private language against which Wittgenstein is arguing in his Philosophical Investigations. Even though there has been no coherent theory of solipsism in the history of philosophy, it spells out the consequences of the widespread view that the individual gets his own psychological and mental concepts only from "his own case", that is, by abstraction or reference to his private "inner experience". Solipsism reveals the common ground of both empirical realism and skepticism and thus exposes the fragility of our conception of mind and world. Seen from that vantage point, helping the philosophic fly out of the fly-bottle amounts to a demanding philosophic task: the demonstration of the incoherence and instability of a common view which is so difficult to localize precisely because of its pervading omnipresence.

I think there is no doubt that Wittgenstein's Philosophical Investigations are, on one level, establishing such an argument. They show that the solipsist's Cartesian assumptions - the idea of a privileged access to one's own mind; a language theory which concentrates on denotation; and finally the postulate of an insurmountable gap between the mental and the physical - are all wrong (or have to be understood differently). But still, there remains the question why this struggle against solipsism and its derivatives is of any importance for us, for the readers and interpreters of Wittgenstein's philosophy. If it is true that "Cartesianism" is a view so common that it pervades our everyday life and language - what, then, is the consequence of denying it? And how can defending or criticizing this view be only a question of arguments, of wrong or false assumptions?

I want to suggest that Wittgenstein's philosophical troubles have to be seen in line with the classical ideal of philosophy, as e.g. in Socrates. It is true that Wittgenstein's topics and questions in the Philosophical Investigations seem to be rather technical. As opposed to the questions treated in

\footnotetext{
${ }^{4}$ Cf. MS 149: 67 (in the Bergen Nachlaß); a paradigmatic exposition of this view can be found in Tugendhat 1979, 92.

5 Tugendhat 1979, 94.
} 
Socrates's Apology, it is already hard work to convince someone who does not already have a professional interest that Wittgenstein is indeed discussing important subject matters at all. What is the rather absurd skepticism of other minds compared to the moral incitation that the only life worth living (and eventually dying for) is an examined life, a life striving for the "greatest improvement of the soul"? But Wittgenstein's philosophy continues the antique tradition in two ways. First, he demands a closer examination of one's own doings and sayings, which amounts to a closer examination of one's own life; and secondly, it also demands that, in order to solve the problems of philosophy, it is necessary to transform the subject which is doing philosophy. So even though there is no doubt that Wittgenstein's idea of philosophy is in many respects distinctively modern - he does not, for example, propose any substantive good according to which one should live - he retains or picks up the classical Greek conception that philosophy is a way to form, or better to transform, the self.

In the following, I will first introduce my interpretation of Wittgenstein's understanding of philosophy and how it represents a continuation of the classical ideal. I will then concentrate on the requirement for transforming the subject, comparing this idea with Foucault's notion of a "technology of the self". In a third part, I will try to articulate some consequences of this idea.

\section{I.}

It is Wittgenstein himself who wrote, in a note included in Culture and Value, that the work of philosophy is a "work on oneself". ${ }^{6}$ This selfunderstanding can be defended by looking at the epistemological status of such rather abstract issues as solipsism or the fantasy of a private language. What does it mean, here, to be mistaken? These theories - if they are theories at all - cannot be simply refuted, nor are they just pathological illusions. The modern problem of the relation of mind and world is, as John McDowell reminds us, intimately tied to an equally modern and disenchanted understanding of nature. But still, this modern view is not just a pair of glasses we can put on and take off according to our philosophical

\footnotetext{
${ }^{6} \mathrm{CV}, 24$.
} 
insights. It is coupled with our modern ways of life, which are, of course, in an emphatic way our ways of life, whether we like it or not. Solipsism and Cartesian subjectivism, rightly understood, are not just ideologies; they must be woven into the patterns of our lives, into the way we ordinarily act and think. It is in this sense that Wittgenstein's philosophy aims at selfknowledge: If we take his claim seriously, that language has to be seen as constituting a part of our practical activities, this in turn means that our discursive understandings of ourselves cannot be completely detached from them. So the roots of the philosophical bewitchments that Wittgenstein's philosophy is struggling with cannot be just sought in thoughts, but must be looked for in our actions.

It is thus impossible to separate Wittgenstein's theoretical reasoning from a practical and in particular moral understanding. Neither Wittgenstein's positions nor those he attacks can be reduced to valid or invalid arguments, as if logic alone would be the battlefield. Numerous interpreters, such as Stanley Cavell or Cora Diamond, offer such a reading. ${ }^{7}$ They stress that the "ordinary", as Cavell calls it, is an indispensable source for doing philosophy and Wittgenstein's philosophy calls for an exploration of ordinary, everyday practices. The problem is not just what we do, but our relation to what we do. I quote Cora Diamond: "Our practices are exploratory, and it is indeed only through such exploration that we come to see fully what it was that we ourselves thought or wanted to say.",

According to Diamond, the goal of the exploratory practice of philosophy is to see better what it was that we "thought or wanted to say". Diamond is adopting here a well-known antique vocabulary. For Greek and Hellenistic philosophy, theory was literally seeing, a way to see things; the analogy between knowledge and vision ranges from Plato up to the Enlightenment. And it is indeed surprising how often Wittgenstein refers to visual metaphors in the Philosophical Investigations. Think, for example, of the image that held us captive ( $(115)$, or of Wittgenstein's request: "Don't think, but look!" (§66) Both Cavell and Diamond rightly agree that one of Wittgenstein's central goals in philosophy is to teach us to see things, and people, differently. And the consequence of such a different

\footnotetext{
${ }^{7}$ Cavell 1979; Diamond 1991.

${ }^{8}$ Diamond 1991, 27.
} 
view, its practical implication, is of course a different way of acting and judging.

This idea of philosophy leading to a different view allows us to formulate the second Socratic aspect in Wittgenstein's philosophy. The first one being that philosophy is concerned with an examination of one's own life, this examination now turns out to be an attempt to gain a new point of view, a new perspective. Socrates wants to stir up the Athenians in their complacency, wants them to realize how shaky the moral foundations of their lives are. In the same manner, Wittgenstein hopes that philosophy can lead us, against our instinctive reactions, out of the fly-bottle by teaching us to see (and to value) things differently. And yet, this different "way of seeing" is not just a new interpretation of things. It is more than the acquisition of a new vocabulary; rather, it is thought of as a real discovery which concerns the subject and the world as a whole. Considering Wittgenstein's insistence that even the most private subjectivity is pervaded by public language and its public schemes of use, such a change affects the subject as such - that is, the way we act, react and judge.

\section{II.}

The interesting question is now, of course: How can such a change be realized? And why is it worthwhile to see things differently? Concerning the latter, I think that Wittgenstein is, like Heidegger, inherently modern in the sense that he does not propose any general direction for change. Wittgenstein's philosophy begins with the fact that we don't know our way about ${ }^{9}$ and thus presupposes that we have a genuine interest in seeing things differently. If there's no problem, philosophy is of no avail. We do, in fact, misunderstand ourselves, so we should command a clear view of what we really mean; we entangle ourselves in our practices, so we should check what we are really expecting from them.

While Wittgenstein proves, in this respect, to be quite modern, the pivotal idea that philosophy changes the way we see things (and ourselves) turns out to be rather classical. The French historian of philosophy, Pierre Hadot, argues that Greek and Hellenistic antiquity was dominated by the

\footnotetext{
${ }^{9} \mathrm{PI}, \S 154$.
} 
idea that philosophy has to be more than just dialog or discursive reasoning. For Greek thinking, truth is not something that can be readily attained by just being a human being. Rather, it is to be acquired through forms of practice: meditation, for example, and other forms of spiritual exercises. ${ }^{10}$ Michel Foucault picks up on this idea and extends it to the general notion of "technologies of the self". A spiritual exercise, in Hadot's sense, is a classical technology of the self: It aims at a transformation of the relation of the self to itself through a continuous bodily and discursive practice. This practice resembles the exercise of an art more than the methodologically controlled pursuit of science, it is a technique, a techné. But Foucault leaves no doubt that technologies of the self extend to a much wider field. Psychoanalysis or the more and more fashionable practice of 'life coaching', for example, are other, more recent technologies of the self.

It seems to me that this concept of a technology of the self captures what Wittgenstein's philosophy is about well. First of all, Wittgenstein's late philosophy lends itself quite naturally to a practical notion of the self. The self is not some immaterial substance, but the relation we entertain to our own bodily, linguistic and even cognitive reactions; it is a practical form of reflexivity. The interesting point is that with Wittgenstein, this practical self has to be thought of as being something to be practically explored. How should we understand phrases like "we don't know our way about" otherwise? What surprises us, in philosophy, is some discordance between the way we understand ourselves and the reactions we display.

This discordance is explored in a practice of imagination. Wittgenstein's writings do not only argue; very often, they ask us to imagine this or that. These imaginary scenarios are tools of self-discovery: We learn, by reflecting about whether we would accept this or that imagined scenario, about the reach and the content of our everyday language and practices. Wittgenstein's philosophical practice mostly consists in asking us (that is, in asking us to ask ourselves) to what extend this or that expression "fits or fails to fit the objects and situations placed imaginatively before us." ${ }^{\text {"11 }} \mathrm{We}$ try to better understand ourselves by probing our possible reactions in con-

\footnotetext{
${ }^{10}$ Cf. Hadot 2002.

${ }^{11}$ Cerbone 1994, 165.
} 
frontation with some imagined scenario, thus disclosing what our real necessities are.

I think there is no problem in calling such an inquiry a technique, or technology, of the self. But in doing so, we acquire a wider perspective on this philosophical practice. It allows us to see a striking similarity between the practice of philosophy, as described so far, and the practice of language acquisition in general. Let me list three common points.

The first observation is that, for Wittgenstein, both kinds of practices, language acquisition and the philosophical practice, operate through training. You don't just understand the meaning of a word; you learn how to use it, with all the well-known problems of rule-following and its contingencies. Understanding, then, and the normativity of rules is something we are able to describe after having gone through this training. There is, in fact, a long discussion about that relation ex post to our own doings in the Remarks on the Foundations of Mathematics, using the example of the mathematical proof. ${ }^{12}$ For Wittgenstein, even the mathematical proof requires a skilled technique whose normativity is established after we have become convinced of the necessity of the proof. That is, first we do something - guided, for example, by some other rules, or by the helping hand of a teacher - and then we establish a new perspective on what we do. Wittgenstein explicitly says about this process that we learn to see our actions differently. So the change effected by a philosophical practice is just an instance of our general possibility to acquire new meanings and understandings through training and regulated use.

The second point is that both the linguistic and the philosophic practice rely on exemplary, paradigmatic practices and persons. Since real understanding comes after the fact, we do not learn by insight only. We have to learn by imitation, by repeating what we are told to do. This is an intrinsic bodily aspect: training requires repetition, not insight, even though we might learn very fast to justify our training by reference to a rule. Here we have a very interesting similarity with Socrates. Lacking the scientific notion of method, Socrates is convinced that his death would be a loss be-

${ }^{12}$ For a good discussion of Wittgenstein's conception of mathematical proof, see Williams 1999. The "retroactive" effect of rule acquisition - the normativity of a new way of seeing - is the subject of Klaus Puhl (2002). 
yond comparison for the polis of Athens. Why? Because he is such an exemplary teacher, important not so much due to the content of what he teaches (his dialogs often end aporetically), but because of its stirring and even destructive effect. Here again, we find in Wittgenstein a systematic basis of the classical idea that philosophy forms the character rather than just informing it, and that this formation is tightly connected with the exemplary lives and sayings of famous philosophers.

The third common point sums up the preceding two. If it is true that both language acquisition and philosophy have to be seen as bodily practices in which we acquire a new understanding by acquiring new skills and uses, and if it is true that, as Wittgenstein claims, our normative understanding of the rule comes after the fact of our initiation into it, then there is no truth-claim involved in this technology of the self. There is, to be sure, a truth-claim on the side of the teacher: she will use truth in order to justify why the novice has to use an expression this way rather than the other. But truth is not the foundation of our necessities; the necessity we experience in our reactions - the necessity of rule-following - is rooted in our being trained this way rather than the other. I should hasten to remark that his does not imply relativism. On the contrary: It is by detaching truth from necessity that it becomes possible to strive for a new perspective in the name of a truth.

\section{III.}

I hope to have shown that Wittgenstein's late philosophy offers many systematic reasons to describe the practice of philosophy as a rather classical technology of the self. It demands an examination of one's own life; it aims for gaining a new perspective; and this change can, due to the very nature of linguistic normativity, be effected only by way of a nonepistemic, practical training guided by paradigmatic acts and actions.

Before I finish, allow me to discuss some of the consequences of such a reading. When Foucault introduces the notion of a technology of the self, he has a certain question in mind. From the beginning on in his career, Foucault has been grappling with the problem of truth. Coming from a French tradition, which had a rather critical perspective on institutionalized science, he criticized modern individualism for defining a normative truth 
of the individual - what is normal, what is pathological; what is reason, what is madness; what is healthy desire, what is deviant perversion. The notion of the technology of a self, then, introduces a significant shift in perspective on this problem. Instead of just asking how society produces truth-standards, he begins to ask how the individual is led to guide herself by some truth. The notion of a technology of the self allows the question to be formalized: Since the practice of the self is, as we have seen, in itself independent from any truth-claim, it can be seen as a distant description of how we attach ourselves to truth. This allows for a genealogy of truth, or rather: a genealogy of truth in relation to the self. ${ }^{13}$

The unsurprising result of such a formal approach is that there are many different technologies of the self, and not all of them are attached to the philosophical notion of a truth about oneself. Philosophy, seen from this Foucauldian perspective, is just one particular technology of the self among others. (I am not sure whether we should class Wittgenstein's philosophy as one still being attached to truth.) In any case, Foucault's genealogical approach offers a completely different approach to helping the fly out of the fly-bottle. Wittgenstein criticizes the solipsistic fantasy of a private language, which is, of course, a variant of the occidental idea that there is some inner, even hidden truth. He offers us tools and concepts to better understand why this subjectivism must be mistaken, and he can show us that we should instead attend to our own public doings and sayings, woven into a many-voiced pattern of life. But Wittgenstein cannot explain, I believe, why the western civilization developed this strong and tempting idea of a private, inner self. He seems to suggest that it is an inevitable, quasi-natural fate that the philosophic fly gets lost in the fly-bottle. But taking into consideration his own statements about the connection of language, will and even emotion to commonly shared practices, it seems more adequate to ask which historical and social formations made it possible, in the first place, that the fly feels attracted to the fly-bottle at all. To cite Foucault's Nietzschean question: "after all, why truth? Why do we care about truth, and, by the way, more about truth than about ourselves?

${ }^{13}$ Such a "history of truth" is Foucault's last description of his philosophical enterprise; cf. Foucault 2001, 74. 
And why do we care about ourselves only by means of truth?"14 This question, then, requires more than just a better look at ourselves. It calls for an investigation of the institutions and the overarching discursive practices which establish, or better: give form to this occidental "obligation to speak the truth" which Foucault tries to understand. This historical and genealogical approach is more than just an extension of Wittgenstein's incitation to have a better look at ourselves. It transcends the realm of the ordinary, since it forces us to understand relations of power, subordination and domination. In short, it demands to confront oneself with society as a reality and not just an abstract form of life. Wittgenstein's philosophy would relapse into some sort of ordinary self-subjectivism if we would not take this step. It is only by a closer look at the reality of social institutions, and not only at our own daily activities, that we might learn to critically understand why certain demands upon us, and certain exigencies, should be accepted, or declined and refused.

${ }^{14}$ Foucault 1994, 723. (my translation) 


\section{Literature}

Cavell, Stanley 1979: Claim of Reason. Oxford.

Cerbone, David R. 1994: “Don't look but think: Imaginary scenarios in Wittgenstein's later philosophy". Inquiry: An Interdisciplinary Journal of Philosophy 37(2), 159-183.

Diamond, Cora 1991: The Realistic Spirit. Cambridge.

Foucault, Michel 1992: History of Sexuality, vol. 2. London.

Foucault, Michel 1994: Dits et Ecrits, vol. IV. Paris.

Foucault, Michel 2001: Fearless Speech. Los Angeles: Semiotext(e).

Hadot, Pierre 2002: Exercices spirituels et philosophie antique. Paris: Albin Michel.

Hadot, Pierre 2004: Wittgenstein et les limites du langage. Paris: Vrin.

Puhl, Klaus 2002: “Die List der Regel”. In: Baltzer, Ulrich / Schönrich, Gerhard (eds.): Institutionen und Regelfolgen. Paderborn: mentis, 81-100.

Tugendhat, Ernst 1979: Selbstbewußtsein und Selbstbestimmung. Frankfurt a. M.: Suhrkamp.

Williams, Meredith 1999 "The philosophical significance of learning in the later Wittgenstein". In: Wittgenstein, Mind and Meaning. London: Routledge, 188-215.

Wittgenstein, Ludwig 1998: Culture and Value. Oxford: Blackwell. (CV)

Wittgenstein, Ludwig 1997: Philosophical Investigations. $2^{\text {nd }}$ Edition. Oxford: Blackwell. (PI) 
